\title{
Island archaeology, identity and resilience in Menorca through the Roman Epoch
}

\author{
Margaret A. Amundson \\ Seminari de Topografia Antiga, Universitat Rovira i Virgili, Spain \\ margaret.a.amundson@gmail.com
}

\begin{abstract}
The ancient Talayotic Culture of Menorca can be best distinguished from that of Mallorca through peculiarities in its monumental architecture. This paper examines the social significance of Menorca's megalithic structures, known as 'taulas'. The construction of such visible monuments within the island's cultural landscape at a time when foreign relations were increasing is significant in that it could suggest a conscious desire for differentiation from Mallorca, its larger and nearest Balearic Island neighbor. This article proposes that these monuments might have functioned as a source of social resilience for indigenous Menorcans, fostering and enabling the persistence of a distinct identity throughout the Roman epoch when the presence of Roman military personnel on the island further intensified foreign cultural interactions. Active engagement in identity curation might also have provided a sense of sovereignty within the broader 'globalizing' hegemony of the Roman Empire. The apparent latitude with which this seems to have been carried out also calls into question broadly accepted narratives regarding the Roman presence in Menorca.
\end{abstract}

Keywords: Balearic Islands, identity, island archaeology, islands, Roman imperialism, social memory, sovereignty

https://doi.org/10.24043/isj.148 • Received October 2019, Early access December 2020

(C) Island Studies Journal, 2021

\section{Introduction}

Both the geography and morphology of Menorca (Balearic Islands, Spain) impacted significantly on its ancient historical destination. In antiquity, Menorca could not have been considered a valuable territory in terms of its intrinsic physical resources, accessibility, proximity to key coastal centers, or its size relative to Mallorca, its nearest archipelagic neighbor. While the availability of fresh water supplies was certainly important to travellers, commercially cultivable land and extractable mineral and metal resources were overall lacking. Nevertheless, Menorca was strategic due to its centrality amid western maritime trade routes and its immense natural port of Maó/Mahon in the south of the island, which had the capacity to accommodate an entire naval fleet. Although it was described as a fertile island (Strab. 3.5.1; Diod. 5.17), the archaeological record suggests Menorca's indigenous inhabitants relied rather heavily on external trade to obtain extrinsic commodities like olive oil and wine, and prestige goods, such as fineware ceramics. From the $6^{\text {th }}$ through the $3^{\text {rd }}$ Centuries BC, Greek, 
Punic and Iberian amphorae and other materials from across the Mediterranean were distributed to the Balearic Islands mainly via the then Punic-controlled island of Ebusus (modern Ibiza) (Juan, Nicolás, \& Pons, 2004; Orfila, 2008; Puig Palerm, 2005; see also Moreno Torres, 2005; Ruiz de Arbulo, 1998 for ancient occidental sailing routes).

The common cultural tradition shared by the indigenous inhabitants of Mallorca and Menorca is identified in modern scholarship as the 'Talayotic culture' after the monumental stone tower-like structures with which they are attributed ('talayot' deriving from the Catalan word for 'watchtower'). Nevertheless, even as this common culture was forming around the start of the $1^{\text {st }}$ Millennium BC, some cultural and social differences had already begun to develop on each island according to their own conditions and experiences as early as the late$2^{\text {nd }}$ Millennium BC (Gili et al, 2006; Ramis, 2010). The expansion of a Punic emporium on Ebusus is associated with an increase in foreign trade and cultural contact beginning around the end of the $6^{\text {th }}$ Century. This produced significant social and economic changes in both Mallorca and Menorca, resulting in a more definite cultural schism between them as they transitioned toward a 'Post-Talayotic' cultural phase (De Cet et al, 2012; De Cet et al, 2017; Gornés Hachero, Gual Cerdó, \& Plantalamor Massanet, 1995). The most conspicuous evidence which stands out from that moment of cultural divergence is the appearance of the megalithic structures peculiar to Menorca known as 'taulas'. Although they are generally understood by archaeologists as having had an essentially religious function (Chapman \& Grant, 1997, p. 71; Hoskin, 1985, 1989; Hoskin, Hochsieder \& Knösel, 1990; Mascaró Pasarius, 1958, pp. 34-36; Murray, 1932), this article focuses on the social aspects of taulas as sources and visible manifestations of power, particularly within the context of ancient globalizing processes.

It is conventionally held that the Roman period in Menorca began with the military conquest of the Balearic Islands in $123 \mathrm{BC}$ by the Roman consul, Quintus Caecilius Metellus (subsequently surnamed Balearicus). Conversely, some authors have argued that the entry of the Balearics into the Roman imperialist sphere was not simply a consequence of conquest in $123 \mathrm{BC}$, but was rather a process which had begun centuries earlier, potentially rooted as early as the $4^{\text {th }}$ Century (Guerrero Ayuso, Calvo Trias, \& Salvà Simonet, 2007; Puig Palerm, 2005). Although native Menorcans would have had an awareness of Rome prior to $123 \mathrm{BC}$, throughout the ancient world Rome existed for many only in the imagination. Connecting with a type of global institution such as the Roman army resulted in the dissemination of artifacts and particular practices throughout the known world from which a conception of 'Rome' manifested as a global consciousness in localized ways (Lawrence \& Trifilò, 2015). The tendency of modern scholarship to view indigenous Menorcans as victims of conquest and imperial domination (Guerrero Ayuso et al, 2007, pp. 79-81; Nicolás, 1983, 2003; Orfila, 2007,2008 ) has effectively relegated them to the role of passive receptors of Roman culture and administration. On the contrary, as Rome's interest in Menorca appears to have been confined to its littoral, its native population, based mainly in the interior, seems to have retained a reasonably high level of autonomy (Amundson, 2020). Therefore, this paper argues for the agency of indigenous Menorcans as curators of their own unique island identity, and proposes that taulas functioned as sources of social memory and resilience throughout the Roman epoch. 


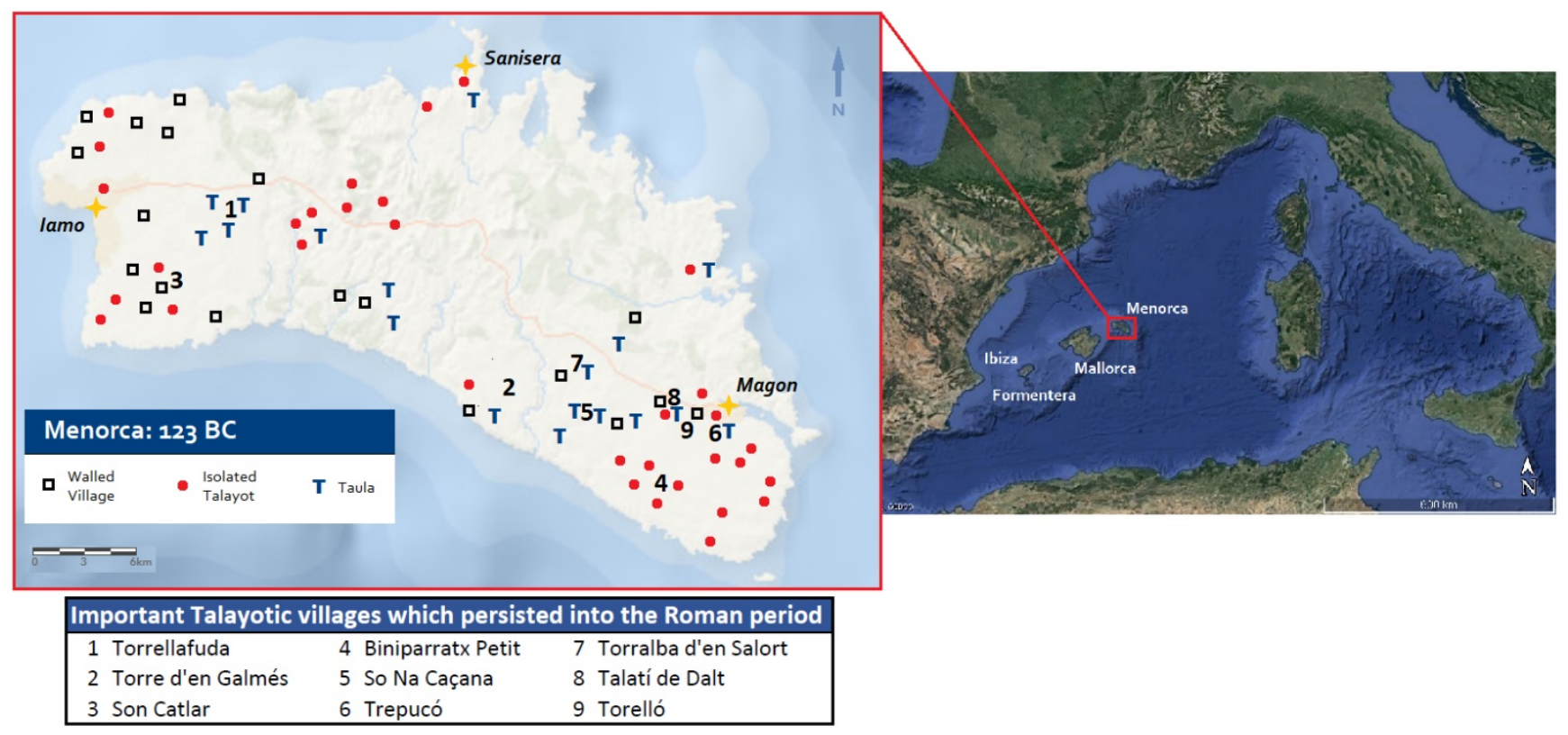

Figure 1. The Balearic Island of Menorca in approximately $123 \mathrm{BC}$ : its location within the western Mediterranean (adapted from Google Earth: (C) 2019 Data SIO, NOAA, U.S. Navy, NGA, GEBCO, Landsat/Copernicus, Google), and its Roman cities and geographical distribution of important indigenous settlements and cultural sites (C) Margaret Amundson, 2019; base map: 'Ocean Base' (C) 2014 Esri; based on Guerrero Ayuso et al, 2006, p. 170).

\section{The ancient geographical, economic and cultural situation of Menorca}

Located approximately $200 \mathrm{~km}$ southeast of Barcelona in the Mediterranean Sea, Menorca is the second-largest island in the Balearic archipelago. It also forms the easternmost edge of the Baetic System, a continental mountain range which proceeds partially underwater off the eastern coast of Spain. Probably due to its being located on the outermost edge of this range, Menorca possesses notably different geological characteristics to the other Balearic Islands and the rest of the Baetic System (Juan i Benejam, 1993, p. 15; Fornós \& Ahr, 1997; Gelabert Ferrer, 2003; Van Strydonck, 2014, p. 25). The entire northern coastline of the island is comprised mostly of rocky cliff faces, with numerous natural coves and small ports. As much of Menorca's geological morphology renders it unsuitable for large-scale agriculture (Juan i Benejam, 1993, p. 16), animal husbandry is thought to have provided an important means of subsistence since ancient times (Pérez-Jordà et al, 2018).

Menorca's location relative to other bodies of land and the maritime conditions which govern its accessibility within the western Mediterranean were undoubtedly important factors in the formation of its external relationships. Pliny (Nat., 3.74, 76-78) makes reference to the relationship of the Balearic Islands with the South of France, specifically with the Narbonense, and Strabo (3.2.5) notes the proximity of Ebusus to North Africa. Additionally, the open route from the Balearics to Sicily and Sardinia was often used as a return route from Hispania to Italy, or via the Strait of Bonifacio directly to Ostia and Rome. The archipelago provided a good stopover for making repairs to ships, or for resupplying and taking on more water before a potentially difficult voyage across open water. Menorca would have been the last port of call for many ships undertaking such journeys. 
Nevertheless, locality means little in the absence of accessibility. In the area of the Balearics, winds originating from the north dominate regional weather. Lying fully outside the Pyrenean lee which provides a degree of shelter to the other Balearic Islands, Menorca receives the full force of North Atlantic winds which tend to grow in intensity as they funnel along the northern Pyrenees toward the southern coast of France and arc past Cap de Creus on a collision course with Menorca. The force of this northern wind, known in Spanish as the 'tramuntana', is evident in a morphological comparison of Menorca's northern and southern coastlines. The wave action generated by the tramuntana has carved out numerous inlets and coves from the north shore's dramatic rocky cliffs. As specific knowledge about various marine hazards and safe anchorages would have been necessary in order to make use of that coast, most merchants would have considered the prospect of trading there on any regular basis to be unprofitable (Guerrero Ayuso, 2010). Alternatively, a southern approach to any of the Balearic Islands is viewed as the easiest and safest for making landfall, as the sirocco (southern wind) does not typically blow with the same intensity as the tramuntana.

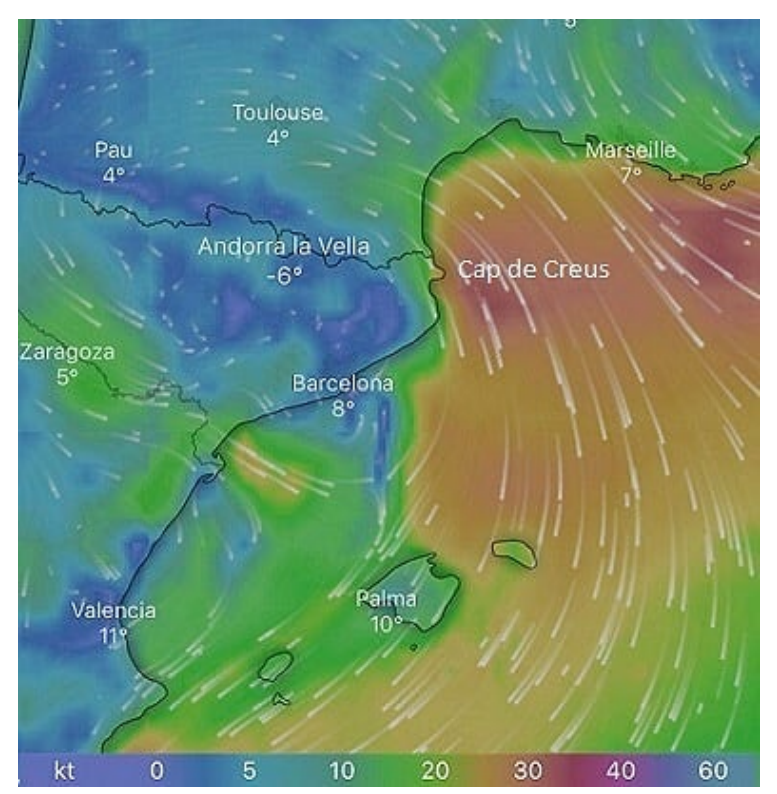

Figure 2. Example of the speed and direction of winds which might be observed in a typical tramuntana weather system. Such wind patterns are more common in winter when historically the sailing season would be closed but also occur frequently in summer. Note the intensity of wind speed localized near the Cap de Creus where storms can develop suddenly, causing shipwrecks on the northern coast of Menorca. Source: Windy.com, 18 March 2019, 07:00.

While the initial human colonization of the Balearics remains a topic of some debate, and is therefore subject to revision, recent research suggests they had become more or less permanently occupied from the second half of the $3^{\text {rd }}$ Millennium BC (Casasnovas, 2007, p. 46, p. 839; De Cet et al, 2012, pp. 390-391; De Cet et al, 2017, p. 148; Ramis, 2010, p. 64). Menorca's cultural evolution has been stratified into four phases, the chronology of which are still widely debated. With a view to discussing the Roman epoch in Menorca, however, this paper concerns mainly the Talayotic and Post-Talayotic periods, with the Talayotic period having lasted from approximately 850-550/500 BC, and the Post-Talayotic from around 550/500-123 BC (Micó, 2006). For simplification, however, indigenous Menorcans 
may be referred to more generally as 'Talayotic'. It should be understood that the mentioning of these periods is mainly to provide temporal reference points based on observed cultural phases. Rather than enter into debates over precise chronologies, the greater objective of this paper is to take a more longue durée examination of certain socio-cultural processes which transcended these phases, but which were nevertheless bound up with them.

In view of some indications of a shared maritime tradition, and similarities in funerary structures and material culture in general, close links appear to have existed between the Bronze Age communities of Mallorca and Menorca (Calvo et al, 2011, p. 360; Gili et al, 2006, p. 835; Ramis, 2010, p. 75). Given local demographic data for Menorca in the $2^{\text {nd }}$ Millennium BC indicating a stable population despite various phases of immigration, continuity in cultural development based on earlier traditions implies newcomers were quickly assimilated into the local social and economic organization (Gili et al, 2006, pp. 839840). Coinciding with the appearance of specialized weapons and defensive structures during the period roughly 1050-850 BC, however, the social and ideological values which had previously emphasized collectiveness and integration began to favor ritual differentiation of individuals, as indicated by the contemporary efflorescence of navetes, megalithic chamber tombs found only in Menorca (Calvo et al, 2012). Such labor-intensive projects suggest social organization, and imply the emergence of a social elite (Knapp, 2009).

By the end of the $6^{\text {th }}$ Century BC, a political, social and commercial restructuring centred around an intensification of maritime commerce began in occidental Phoenician colonies such as those which had been established on Ebusus (Ibiza) as early as the $7^{\text {th }}$ Century (Fernández \& Costa, 2006; Guerrero Ayuso et al, 2007). It was during that period of maritime commercial expansion that some of the first Punic Ebusitan amphora forms began to circulate within the Balearic archipelago and the wider western Mediterranean. Through exchange relationships fostered and regulated by Ebusus, eastern Mediterranean building materials and techniques, and cultural and religious iconography, were introduced in Menorca. Votive figurines of eastern Mediterranean deities have been recovered from ritual and funerary contexts (Fernández-Miranda, 1981; Guerrero Ayuso, Calvo Trias, \& Gornés Hachero, 2006; Guerrero Ayuso et al, 2007; Roselló-Bordoy, Sánchez-Cuenca \& Montaner Alonso, 1974), and the villages of Son Catlar, located in the municipality of Ciutadella in the north of the island, and Torre d'en Galmés in the south, provide interesting examples of a mixture of Punic (and possibly Greek) architectural influences (Juan i Benejam, 1993, p. 60; Prados, Jiménez, \& Martínez, 2017; Orfila Pons \& Taltavull Femenías, 1996, pp. 21-23). The sudden introduction of a distinct new form of ritual architecture around the same time, the taula, may have been a local response to exposure to foreign influences through trade.

\section{Taulas, identity and memory}

Taulas (meaning 'table' in Catalan) are large, man-made features consisting of two megalithic stones positioned one on top of the other in such a way that together they form a ' $\mathrm{T}$ ' or table shape. It is not uncommon for these structures to exceed five meters in height, and two to three meters in width. Taulas are enclosed within a horseshoe-shaped wall, constructed in the cyclopean technique, which is open at a lintelled doorway at the main facade of the taula. These ritual sanctuaries, also called 'taula precincts', follow a more-or-less generalized pattern, with the walled interior divided into separate sections by pilasters crowned with capitals which would have exceeded the height of the wall. In some cases, the presence of bonfires have 
been documented, contained by stone fire rings - usually to the right of the taula - within which fragments of ceramics and domesticated faunal remains have been detected (Gornés Hachero, 2008). Such evidence, taken together with the fact that the walls of the precinct are not designed to support a large roof of stone slabs or wood beams (and at any rate, no such material has been found), supports the hypothesis that they were open-air structures (Gornés Hachero, 2008), and indeed may have served an astrological function, as proposed by Hoskin and others (Hoskin, 1985, 1989; Hoskin et al, 1990).

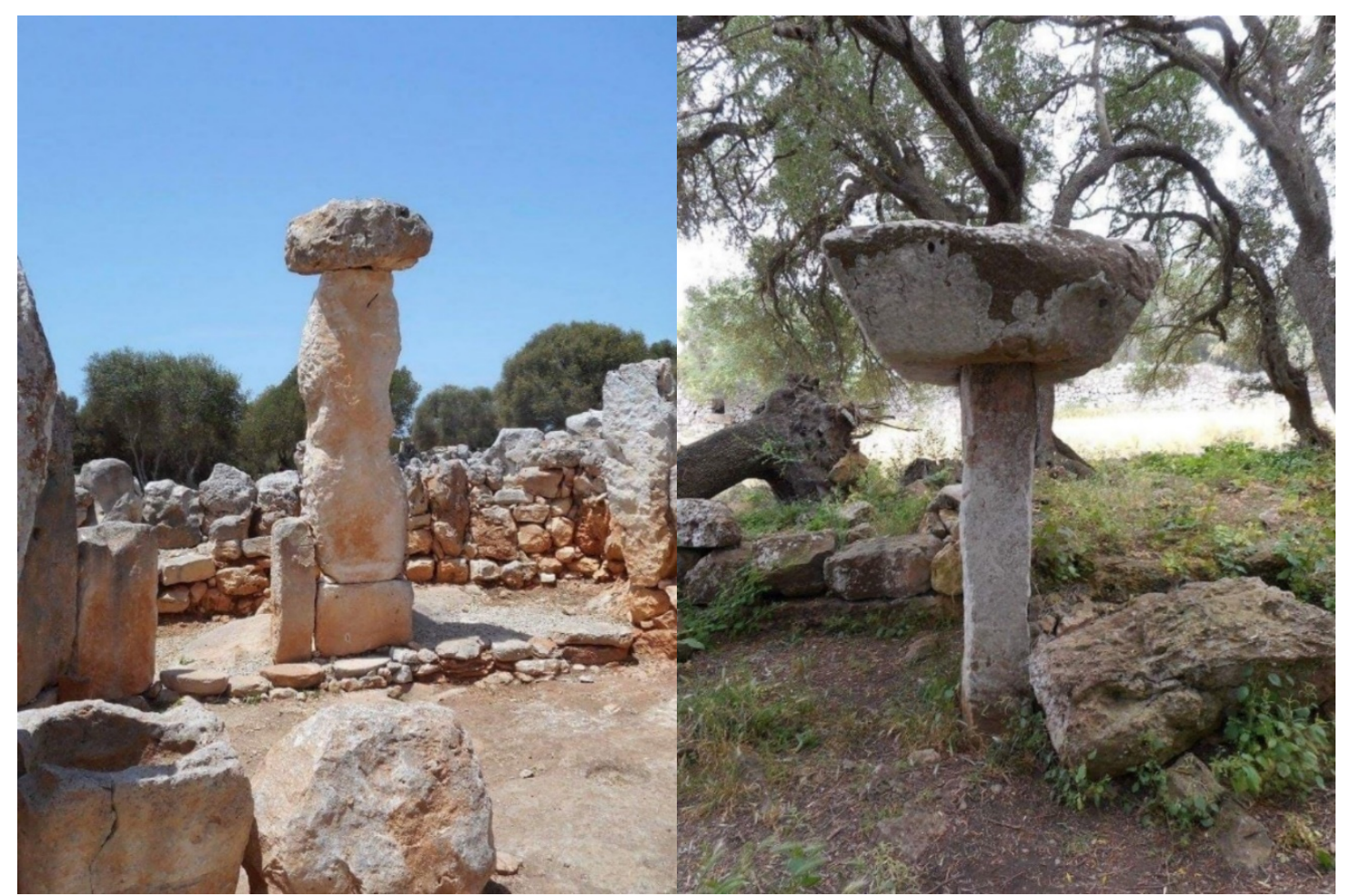

Figures 3 \& 4 . Taulas at the Talayotic settlements of Torre d'en Galmés (left) and Torrellafuda (right). Photos: (C) Wilder Herron, 2016, with permission.

Though more precise dating is still needed, the rapid appearance (in archaeological terms) of taulas in Menorca rules out a gradual ritual evolution occurring in a state of isolation. Biogeography and environment cannot explain such a sudden change after a millennium of little differentiation. On the contrary, it has been observed that "the Bronze Age society of Menorca, far from being static or isolated, incorporated certain innovations very rapidly from new populations or from the long-distance exchange networks in which it participated" (Gili et al, 2006, pp. 840-841). The emergence of trade usually stimulates political activity, potentially upsetting long-standing power structures within societies. Some societies respond with economic development geared toward increasing trade participation, as occurred in Mallorca where subsidiary Punic-Ebusitan production centres were established at Puig de Sa Morisca and $\mathrm{Na}$ Guardis (Guerrero Ayuso, 2004). Menorca, on the other hand, with its comparatively limited resources, seems to have intensified its ritual hierarchy through the building of taulas as a source of social power.

The circumstances which prompted a significant period of monumentalization in Malta more than two millennia earlier may provide a clue to understanding the impetus behind Menorca's taulas. Like Menorca, Malta is an island which is relatively distant from continental 
shores, yet shares close proximity to a larger island-in Malta's case, Sicily. In terms of trade, both Malta and Menorca can be considered as "outliers in an extended exchange network, on the edge of the visible world" (Boomert \& Bright, 2007, pp. 13-14). Malta and Sicily, too, exhibited some shared culture until external trade contacts began to increase in the early $4^{\text {th }}$ Millennium BC (Bonanno, 2008, p. 30). From that point, Maltese culture took a completely different trajectory, initiating the monumental 'Temple Period'. What is illustrative for scholars of Menorca is how Malta's monumental architecture has been recognized not simply as the result of internal ritual development, but as a strategy for the creation of a distinct island identity through which the Maltese could differentiate from their Sicilian neighbors with whom they had become increasingly associated through exchange relationships (Bonanno et al, 1990; Robb, 2001).

The centralization of political and ritual power required to realize monumental construction indicates the presence of unequal social systems. Monuments, as prominent, often dominant features in the landscape, can provide a material means for elites to establish or reiterate their identity and authority (Knapp, 2009). The construction of taulas likely helped maintain relationships of power which had formed in the early Talayotic period. In other Mediterranean island societies (for example, Late Bronze Age Cyprus), elite identity and ideology were sometimes closely linked to monumentality, ritual and the consumption of exotica (Knapp 2009, p. 56). From an archaeological perspective, the most intense arrival of goods to Menorca coincided with periods of conflict in which Balearic warriors were recruited as mercenaries, primarily the Punic Wars. These goods included mainly commodities such as non-indigenous food products and crockery, though whether they should be viewed as spoils of war or bartering fees for mercenaries is unclear (Orfila, 2008, pp. 11-12; Puig Palerm, 2005, pp. 249-250). At any rate, through their participation in the Punic Wars, Menorca's native warriors would have been exposed to alien societies, some of which no doubt possessed greater material wealth or appeared to enjoy better qualities of life. Such privileged contact with the foreign might also have been an important asset in internal politics, leadership, and social mobility (Robb, 2001, pp. 190-191). Known by the Latin name, funditor, these specialist warriors, whose signature weapon was a powerful sling which was used to hurl lead ingots or stones at enemies with deadly force and accuracy, were described as being very formidable and were highly valued as mercenaries in the Punic Wars. Probably already well-respected in their communities as an elite warrior class, funditores may have improved upon or acquired a social elite status after fighting abroad.

Introduction to the foreign or exotic necessarily results in an awareness of local difference, by virtue of their opposition. In Menorca, any periods during which foreign contact was intensified would only have served to heighten this awareness. Whether foreignness was perceived positively or negatively, the islanders would have been confronted with a choice. They could choose to shun the foreign in favor of a closed isolation, or they could remain open, receptive to outside ideas (Broodbank, 2000, pp. 18-19). The archaeological record of Menorca indicates they may have invented a third option, a strategy for mediating opposition between local and foreign. The building of taulas and the cultural appropriation of exotica, especially within those places which symbolized Menorca's ritual differentiation from Mallorca, signify intentional creation and reinforcement of cultural difference. Where trade and ritual might have posed contradictory principles in the local culture, the social relations of trade appear to have been integrated into the hegemony of 
ritual through domestication of the exotic and covert incorporation of the foreign into local difference (Robb, 2001, p. 189). Discoveries of foreign idols in taula sanctuaries, such as the well-known bronze figures of the Egyptian god Imhotep at Torre d'en Galmés (FernándezMiranda, 1981) and a bull at Torralba d'en Salort (Roselló-Bordoy et al, 1974), support this hypothesis. As Robb (2001, p. 194) observed of Malta's temple society: “one effect of [temple-based] rituals may have been to sublimate internal divisions-a temporary recreation of a period of original unity in a socially divided society." Such an adaptive strategy, manifesting as a discrete identity, would have provided native Menorcans with a high level of social resilience, especially within globalizing contexts.

Over the last 50 years, a large body of work has evolved around the study of monumental structures in archaeology, particularly within the islands of the Mediterranean (Brysbaert et al, 2018; Knapp, 2009; Kolb, 2011, 2014; Osborne, 2014, 2017; Renfrew, 1976, 1983, 2013; Tilley, 1994; Trigger, 1990; Vella, 2016). From these sources, we have begun to see monuments as culturally constructed 'places', enduring features of the landscape which give structure and spatial definition to psychological and social experiences. Monuments begin to acquire agency from the circumstances of their conception, through communal engagement in their construction, and over time as repetition of social experiences related to the monument become memory. The specialized knowledge, combined resources and community effort which would have been required to build a megalithic structure such as a taula must have helped create a collective social identity among the contributors as they shared in an achievement which was greater than the sum of its parts. After their construction, taula sanctuaries, as social spaces where ritual activities were carried out, would have served to establish memories, manifest social identity and maintain local history. As indelible 'places' of specific social, historical and political configurations, taulas would also have provided a sense of continuity and stability. Indeed, talayots remained central points of reference in settlements throughout this time, and taulas are typically found in proximity to talayots.

The Talayotic Culture is broadly considered to have effectively ended with the Roman 'conquest' of the Balearic Islands in 123 BC (but see Amundson, 2020). As Smith (2015, p. 57) remarked, "it is during the Roman period that the inhabitants are no longer considered even Late Talayotic, but simply subjects of a larger colonial and subsequently imperial network." That is, as far as archaeological study of Roman Menorca has been concerned, the indigenous Menorcans are wholly subsumed by the Roman imperial machine. They lose all identity and are spoken of no more except in terms of their 'Romanization'. However, as with any cultural transition, it is not practical to draw such lines of demarcation through history based on a single year or event. Referring to Bronze Age Menorca, Gili et al (2006, p. 840) concluded that "funerary practices and, in particular, monumental architecture enabled the population of Menorca to express differences in ideology, and at the same time maintain a high degree of social cohesion and stability over more than one thousand years." This article proposes to extend that observation by possibly as many as another thousand years.

\section{The Roman Epoch in Menorca}

Having won territorial dominion over the Balearic Islands from Carthage at the conclusion of the Punic Wars in 146 BC (Liv. 30.30.24-25), it was not until piracy based among the islands became a substantial liability to maritime trade that Rome actually intervened in the 
islands' autonomy. According to the historical record, consul Q. Metellus was charged with leading a military operation in the Balearic Islands in $123 \mathrm{BC}$ in order to address an outbreak of piracy emanating from there (Strab., 3.5.1-2; Flor., 1.43; Oros., 5.13.1). Though imperialistic in scope and effect, Rome's intention towards Menorca clearly was not territorialization (see Amundson, 2020). This is an important distinction as it informed the nature and extent of Roman engagement with the island.

Curiously, Menorca's archaeological record provides no evidence for either an islandwide resistance or a violent suppression, with only partial abandonment of rural settlements and no clear evidence of destruction which can be dated conclusively to this event. Instead, the facility with which Roman soldiers appear to have integrated into indigenous communities thereafter (see below) is more consistent with a previously established affiliation between the islanders and Rome. Indeed, Livy (22.20.9; 28.37.7-15) recorded that the Balearic Islands had changed alliances during the Second Punic War, after which Balearic mercenaries were enlisted by Rome, and would have fought alongside Roman soldiers in mixed armies. Surely, such a relationship would negate any necessity for an attack on the island's residential population. On the other hand, even if no affiliation existed between Talayotic Menorcans and Rome, throughout the Bronze and Iron Ages the archaeological record of Menorca shows evidence of the development of specific integration strategies which enabled the prehistoric people of Menorca to maintain a high degree of social cohesion and stability during elevated periods of immigration (De Cet et al, 2017). A willingness towards integration rather than opposition is more characteristic of a peaceful people, consistent with the description of the islanders provided by Strabo (3.5.1), and also makes a general conquest seem both unnecessary and unlikely.

The written record mentions no immediate imposition of legal control over Menorca itself, but rather describes a simple military operation to rid the island of pirates. For Rome, coastal defence would have been difficult and costly as it entailed protection of the shore, not only against invasions in time of war, but also against sporadic piratical incursions on an ongoing basis. To maintain littoral security, Rome opted for a primarily 'passive' defence strategy, which consisted of fortifying the shoreline itself, and probably also included an 'active' patrol of the island's beaches, coves and surrounding seas (Starr, 1943, p. 56). It is significant that just three Roman cities in Menorca are known from the historical recordsIamo (Ciutadella/Ciudadela), Magon (Maó/Mahon) and Sanisera (Sa Nitja) (Plin., Nat. 3.11) - and that they were each located at natural ports more or less equidistant around the island. Possibly as a cost-effective measure, defensive resources were allocated mainly to areas of higher commercial traffic. Iamo and Magon are believed to have had Punic foundations (Ramón Torres, 2017, p. 41; Sánchez León, 2003, p. 101), whereas Sanisera was the only original settlement founded on the island by the Romans following Metellus' campaign, with every indication that its purpose was as little more than a simple military base (Nicolás Mascaró, 2003). The installation of military garrisons at each of Menorca's three most practicable ports, and nowhere else in the interior, supports the assertion that Rome's interest in the island was entirely maritime oriented (Amundson, 2020).

The process of organizing a provincial government and instituting a legal administration over the indigenous population appears to have been significantly retarded in Menorca as compared to Mallorca and Ebusus (García Riaza \& Sánchez León, 2000). Although Metellus was likely the first official administrator of the Balearic Islands, as part of 
the jurisdiction of his prefecture in Hispania, the first Balearic prefect with a certain date (based on epigraphical sources from Tarraconensis) is listed as Lucio Titinio Glauco Lucreziano, administrator of the islands from 63-65 AD (Sánchez León, 2000, p. 30; Zucca, 1998, p. 111). Rather unhelpfully, this evidence dates a full 186 years after Metellus's campaign, and it reveals little about what level of control was actually exercised in Menorca, specifically. In any case, Zucca (1998) points out that the duty of the praefectus maritimus, endowed with military authority, was more to patrol the coasts as a deterrent against brigands. Until the first century AD when Vespasian introduced Flavian municipal law to all of Hispania (including the Balearics), nearly 200 years after the Roman 'conquest' of the Balearics, few indications of interior government or imperial inclusivity have been identified in Menorca. Epigraphical sources which definitively prove Menorca's eventual legal recognition and integration into the empire all date to the first and second centuries AD, well after the initial Roman occupation (Nicolás Mascaró, 2003; Sánchez León, 2000, 2003). The discoveries of two inscriptions dedicated to Caracalla are particularly important, as Caracalla had issued his edict in 212 AD granting Roman citizenship to all free inhabitants of the Empire. Only at that point can we say for certain that free inhabitants throughout the island of Menorca were legally included in the Roman Empire. At least until its legalization, Menorca appears to have maintained autonomy in all respects not related to maritime interests.

For example, normal patterns of Roman organization and territorial exploitation have so far been absent from the archaeological record. That is, no confirmed traces have been found of centuriae, villae, nor any other conclusive evidence of territorial allocation or development (Arribas Palau, 1983; Orfila, 1993, 1995; Nicolás Mascaró, 2003). Only in Mallorca has the existence of new settlements dedicated to agricultural exploitation been reliably verified (Orfila, 1993). This contrast emphasizes Rome's lack of interest in Menorca's terrestrial resources. Consequently, the native population seems to have enjoyed a certain latitude with regards to subsistence practices and preferences. Valenzuela, Alcover and Cau (2017, p. 138) have observed that reformations of indigenous animal husbandry practices in Menorca during the Roman period contrasted sharply with Mallorca. Whereas evidence for much higher percentages of cattle and pig has been found in Mallorca, consistent with the Roman diet, sheep and goats remained dominant in Menorca (except in the military garrison at Sanisera, where faunal remains reflected a customary diet for Roman soldiers). Some beneficial modifications to Menorcan livestock breeding practices may have been implemented initially, but further alterations evident in Mallorca do not appear to have been adopted in Menorca, suggesting a lesser Roman influence there (Valenzuela et al, 2017, p. 139).

In the port garrisons, however, the presence of Roman soldiers would have meant greater quantities of imports to the island and the introduction of a wider variety of prestige goods, allowing for a fuller participation in a globalized marketplace. A well-documented exodus from Talayotic villages coinciding with the arrival of the Romans to Menorca has, in some instances, been attributed to their conquest and subjugation of the native population (for example, Arribas Palau, 1983, pp. 40-43, though various authors have subsequently, at times, expressed or implied agreement with this observation). Alternatively, another possibility is that some native islanders quit their villages of their own accord and, as happens in many poor countries, migrated to the cities in search of opportunity. Exposure to the exotic and potential access to prestige goods could have instilled in the Menorcan elite a desire to be included in Roman commerce and society wherein wealth and position might be acquired. Several epigraphical 
markers indicating locally held magistracies and priestly offices have been encountered in both Ciutadella and Maó. Such inscriptions have revealed higher rates of mobility between Iamo and Magon among members of the upper classes in pursuit of opportunities in the first centuries AD (see Sánchez León, 2000, for more detailed evidence and discussion).

Nevertheless, not all of the Talayotic villages were abandoned. In fact, a majority of important villages and ritual sites continued to see activity and revival well into late antiquity (De Cet et al, 2012; Mas et al, 2007; Orfila Pons \& Sintes Espasa, 1984, Pérez-Juez, 2011). Smith and van Dommelen (2018) have highlighted the importance of looking not only at visible signs of use and re-use, but of developing a broader understanding of 'monumental afterlife' in Menorca. Physical engagement with a monument may be continuous, intermittent or discontinued. Even where no later material evidence is found in relation to it, the monument's place in the landscape as a socially and ideologically relevant marker or beacon should still be considered (Smith \& van Dommelen, 2018, p. 162). Smith and others (Smith, 2015, pp. 130-131; 2020; Smith \& van Dommelen, 2018, p. 171) have observed architectural parallels between later Menorcan domestic structures Torre d'en Galmés and taula precincts. A good example is illustrated by the impressive Cartailhac Circle of the Talayotic settlement of Torre d'en Galmés, in the south of the island. The Cartailhac Circle is one of the largest and latest structures at this site, dating to the $3^{\text {rd }}$ Century BC (Sintes \& Isbert, 2009). Unlike Talayotic dwellings found on Mallorca, structures identified as houses on Menorca, such as those at Torre d'en Galmés, include multiple stone columns in a circular configuration (Sintes \& Isbert, 2009, for excavation of Cartailhac Circle; Hernández-Gasch, 2011, for an Iron Age synthesis of circular housing structures specific to Menorca). Reflecting on the striking resemblance of these columns to taulas, Smith and van Dommelen (2018, p. 171) interpret their presence in such architecture as "a hyper-representation of indigenous and past forms and traditions in response to external influences and pressures." They therefore conclude that the houses symbolize the 'afterlives' of Menorcan monuments, not only because of their close spatial juxtaposition, but because the Late Taylayotic people "adopted and adapted older architectural traditions of the island and reworked these into new forms that were equally local and Menorcan" (Smith \& van Dommelen, 2018, p.171).

Surveys at Torre d'en Galmés have produced thousands of Tarraconensis amphora sherds dating from the $1^{\text {st }}$ Centuries $\mathrm{BC}$ and $\mathrm{AD}$, demonstrating intensive use of Roman material culture at this site from the $3^{\text {rd }}$ Century BC to the first century AD (Smith \& Van Dommelen, 2018, p. 166, p. 168, p. 169-fig. 8.4). Prior to the arrival of Metellus and his forces to the shores of Menorca in $123 \mathrm{BC}$, the indigenous population was not ignorant of Roman culture, which in many ways resembled that of the Punic merchants with whom they had dealt directly for centuries. Similarities between the Punic and Roman religions (the Roman religion itself comprising a pan-Mediterranean pantheon), as well as concepts of social hierarchy, likely facilitated an uncommon Roman integration into Talayotic communities. As indicated above, Roman ceramics and building remains have been found within Talayotic settlements, and Roman inhumations and inscriptions in Talayotic necropolises, dating from the $1^{\text {st }}$ and $2^{\text {nd }}$ Centuries AD (Arribas Palau, 1983, p. 48; Nicolás Mascaró, 2003). The villages of Talatí de Dalt, Torre d'en Galmés and Trepucó demonstrate some of the most intensive evidence of Roman influence in their structural modifications (Orfila Pons \& Taltavull Femenías, 1996, p. 39). Votive statuettes of popular Roman Mediterranean deities and bronze votives of provincial figures crafted in Menorca using Roman techniques have been found 
throughout the island, particularly within taula sanctuaries (Moreno Perez, 2012, p. 180; Orfila Pons, 1983). Several bronzes of a local interpretation of the warrior god Mars (dubbed 'Mars Balearicus') have been found near taulas and in a number of Talayotic villages (Orfila Pons, 1983; Orfila et al, 2017). While these integrations and modifications are typically viewed as evidence of Romanization, Broodbank (2000, p. 20) observed that "loss of culture traits, deviation, and curation of archaisms were sometimes strategies through which island identities were created and sustained by people who [knew] how things were done elsewhere."

\section{Conclusions}

Alterations in consumption patterns brought about by conquest and other military operations in the Roman Empire often resulted in the expression or manifestation of new identities. It must be remembered, however, that access does not necessarily translate to adoption, even among those who possess the means for consumption. In the modern globalized world, rather than simply accepting cultural identities as given, individuals have become capable of picking and choosing their own identities through an awareness of a whole range of possibilities that exist across the world (Morely, 2015). Despite its relative geographical isolation and a supply chain ostensibly controlled by Punic Ebusus, the archaeological record of Menorca dating from its earliest contacts with Greek and Phoenician merchants and sailors demonstrates not only exposure to a diversity of foreign religions and cultural artifacts, but also an apparent inclination towards selective incorporation. Rather than a product of biogeography, insularity has been recognized as a form of social identity, a cultural choice manipulated by islanders (Boomert \& Bright, 2007; Broodbank, 2000; Dawson, 2019; Rainbird, 2007; Robb, 2001).

Archaeological evidence from Talayotic sites which persisted through the Roman period suggests that, rather than passive receptors of Roman administration and culture, indigenous Menorcans remained active agents in the curation of their own insular identity. This could be seen as an act of self-determination, providing a sense of sovereignty within a rapidly globalizing Roman hegemony. The significance of taulas as a visible, enduring symbol of differentiation would have undoubtedly furnished a powerful source of social memory which could have manifested as a form of resistance identity. Such identities can foster an ideological strength to opt-out or resist nation state incorporation (Boomert \& Bright, 2007, p. 13; Parker Pearson, 2004). Considered this way, 'Romanization' is a potentially misleading term for the socio-cultural changes which occurred in Menorca during the Roman epoch.

\section{References}

Amundson, M.A. (2020). Managing the threat: A Maritime archaeological study of the island of Menorca as a key ancillary in the Roman Mediterranean. In N. Raad \& C. Cabrera Tejedor (Eds.) Ships, boats, ports, trade, and war in the Mediterranean and beyond: Proceedings of the Maritime Archaeology Graduate Symposium, 2018 (pp. 51-60). BAR Publishing.

Arribas Palau, A. (1983). La Romanització de les Illes Balears. Universitat de les Illes Balears.

Bonanno, A., Gouder, T., Malone, C., \& Stoddart, S. (1990). Monuments in an island society: The Maltese context. World Archaeology, 22(2), 190-205. https://doi.org/10.1080/00438243.1990.9980140 
Boomert, A., \& Bright, A.J. (2007). Island archaeology: In search of a new horizon. Island Studies Journal, 2(1), 3-26.

Broodbank, C. (2000). An island archaeology of the early Cyclades. Cambridge University Press. Brysbaert, A., Klinkenberg, V., Gutiérrez Garcia-M, A., \& Vikatou, I. (Eds.) (2018). Constructing monuments, perceiving monumentality \& the economics of building: Theoretical approaches and methodological approaches to the built environment. Sidestone Press.

Calvo, M., Albero, D., Rosselló, J.G., Javaloyas, D., \& Guerrero, V. (2012). Re-thinking social hierarchisation and stratification in the Bronze Age of the Balearic Islands. In M. Cruz Berrocal, L. García Sanjuán, \& A. Gilman (Eds.), The prehistory of Iberia: Debating early social stratification and the state (pp. 170-202). Routledge.

Calvo, M., Javaloyas, D., Albero, D., Garcia-Rosselló, J., \& Guerrero, V. (2011). The ways people move: Mobility and seascapes in the Balearic Islands during the late Bronze Age (c. 1400- 850/800 BC). World Archaeology, 43(3), 345-363. https://doi.org/10.1080/00438243.2011.605840

Casasnovas, M.A. (2007). Història de les Illes Balears. $2^{\text {nd }}$ ed. Editorial Moll.

Chapman, R., \& Grant, A. (1997). Prehistoric subsistence and monuments in Mallorca. In M.S. Balmuth, A. Gilman, \& L. Prados-Torreira (Eds.), Encounters and transformations: The archaeology of Iberia in transition (pp. 69-88). Sheffield Academic Press.

Dawson, H. (2019). Island archaeology. In C. Smith (Ed.), Encyclopedia of global archaeology (pp. 1-8). Springer Nature. https://doi.org/10.1007/978-3-319-51726-1 3280-1

De Cet, M., Duttmann, R., Gornés, S., Gual, J., Müller, J., Risch, R., Sintes, E., \& Willié, B. (2012). Changing settlement patterns in the Mediterranean context: A case study of Menorca (Balearic Islands) from prehistory to the $19^{\text {th }}$ Century AD. In G. Earl, T. Sly, P. Chrysanthi, P. Murrieta-Flores, C. Papadopoulos, I. Romanowska, \& D. Wheatley (Eds.), Archaeology in the digital era: Papers from the 40 Annual Conference of Computer Applications and Quantitative Methods in Archaeology (CAA) (pp. 389-399). Amsterdam University Press.

De Cet, M., Lull, V., Micó, R., Rihuete, C., \& Risch, R. (2017). Migration and integration during the Bronze and Iron Ages: The case of Menorca. In H.H. Meller, F. Daim, J. Krause, \& R. Risch (Eds.), Migration und Integration von der Urgeschichte bis zum Mittelalter (9. Mitteldeutscher Archäologentag)/Migration and integration from prehistory to the Middle Ages (9th Archaeological Conference of Central Germany) (pp. 145-168). Landesamt für Denkmalpflege und Archäologie Sachsen-Anhalt, Landesmuseum für Vorgeschichte.

Diodorus Siculus. Library of History, Volume III: Books 4.59-8, trans. Oldfather, C.H. (1939). Loeb Classical Library 340. Harvard University Press.

Fernández, J H., \& Costa, B. (2006). Ibiza Fenicio-Púnica. El Mundo-El Día de Baleares. Fernández-Miranda, M. (1981). Taulas de Menorca. Revista de arqueología, 2(4), 6-13.

Florus. Epitome of Roman History, trans. Forster, E.S. (1929). Loeb Classical Library 231. Harvard University Press.

Fornós, J.J., \& Ahr, W.M. (1997). Temperate carbonates on a modern, low-energy, isolated ramp; the Balearic Platform, Spain. Journal of Sedimentary Research, 67(2), 364-373. https://doi.org/10.1306/D4268572-2B26-11D7-8648000102C1865D

García Riaza, E., \& Sánchez León, M.L. (2000). Roma i la municipalización de las Balears. Universitat de les Illes Balears, Servei de Publicacions i Intercanvi Científic. 
Gelabert Ferrer, B. (2003). La estructura geológica de Menorca: las zonas de Tramuntana y Migjorn. In Introducción a la geografía física de Menorca: guía de campo de las XVIII Jornadas de Geografía Física (pp. 39-48). Societat d'Història Natural de les Balears.

Gili, S., Lull, V., Micó, R., Rihuete, C., \& Risch, R. (2006). An island decides: Megalithic burial rites on Menorca. Antiquity, 80(310), 829-842. https://doi.org/10.1017/S0003598X0009445X

Gornés Hachero, J.S. (2008). Nuevas Aportaciones a los Contextos Arqueológicos ya la Cronologia de los Santuarios de Taula de Menorca. In X. Dupré i Raventós, S. Ribichini, \& S. Verger (Eds.), Saturnia Tellus: definizioni dello spazio consacrato in ambiente etrusco, italico, fenicio-punico, iberico e celtico: atti del convegno internazionale svoltosi a Roma dal 10 al 12 novembre 2004 (pp. 489-506). Consiglio Nazionale delle Ricerche.

Gornés Hachero, J.S., Gual Cerdó, J.M., \& Plantalamor Massanet, L. (1995). Material d'importació al talaiòtic final de Menorca: l'abocador de Toraixa (Es Castell) Menorca. Saguntum: Papeles del Laboratorio de Arqueología de Valencia, 28, 167-172.

Guerrero Ayuso, V.M. (2010). ¿Foceos en el comercio tardoarcaico al norte de Baleares?. Mayurqa, 33, 131-160.

Guerrero Ayuso, V.M. (2004). Colonos e indígenas en las Baleares prerromanas. Treballs del Museu Arqueologic d'Eivissa i Formentera, 54, 145-203.

Guerrero Ayuso, V.M., Calvo Trias, M., \& Gornés Hachero, S. (2006). Mallorca y Menorca en la Edad del Hierro (Historia de las Islas Baleares, 2). El Mundo-El Día de Baleares.

Guerrero Ayuso, V.M., Calvo Trias, M., \& Salvà Simonet, B. (2007). Insularity and the indigenous world on the periphery of the system: The Balearic Islands between the $6^{\text {th }}$ and the $1^{\text {st }}$ c. B.C. In P. van Dommelen \& N. Terrenato (Eds.). Articulating local cultures: Power and identity under the expanding Roman Republic. JRA Supplementary Series, 63, 71-84.

Harmanşah, Ö. (2014). Place, memory, and healing: An archaeology of Anatolian rock monuments. Routledge.

Hernández-Gasch, J. (2011). Privatització i diversificació de l'espai domèstic en la societat balear de l'Edat del Ferro. III Jornades d'Arqueologia de Les Illes Balears (Maó 2008), 43-62.

Hoskin, M. (1989). The orientations of the taulas of Menorca (1): The southern taulas. Archaeoastronomy Supplement, 14, S117.

Hoskin, M. (1985). The Talayotic culture of Menorca: A first reconnaissance. Journal for the History of Astronomy, 16(9), S133-S151. https://doi.org/10.1177\%2F002182868501600906

Hoskin, M., Hochsieder, P., \& Knösel, D. (1990). The orientations of the taulas of Menorca (2): The remaining taulas. Journal for the History of Astronomy, 21(15), S37-S48. https://doi.org/10.1177\%2F002182869002101504

Juan, G., Nicolás, J.C. de, \& Pons, O. (2004). Menorca, segle IV-II, un mercat per al comerç ebusità. In J. Sanmartí, D. Ugolini, J. Ramon, \& D. Asensio (Eds.), Actes de la II Reunió Internacional d'Arqueologia de Calafell: La circulació d'àmfores al Mediterrani occidental durant la Protohistòria (segles VIII-III aC): aspectes quantitatius i anàlisi de continguts (pp. 261-264). Universitat de Barcelona.

Juan i Benejam, G. (1993). El poblament de Menorca: de la Prehistòria a la Baixa Romanitat: aproximació a una proposta d'anàlisi de distribució espacial (Treballs del Museu de Menorca, 13). Conselleria de Cultura, Educació i Esports, Govern. Balear. 
Knapp, B. (2009). Monumental architecture, identity and memory. Proceedings of the Symposium: Bronze Age Architectural Traditions in the EastMediterranean: Diffusion and Diversity (pp. 47-49). Weilheim i. OB: Verein zur Förderung und Aufarbeitung der Hellenischen Geschichte.

Kolb, M.J. (2011). The genesis of monuments in island societies. In M.E. Smith (Ed.), The comparative archaeology of complex societies (pp. 138-164). Cambridge University Press.

Kolb, M.J. (2014). Monumentality among the Mediterranean Isles. In J.F. Osborne (Ed.), Approaching monumentality in archaeology (pp. 153-180). SUNY Press.

Lawrence, R., \& Trifilò, F. (2015). The global and local in the Roman empire: Connectivity and mobility from an urban perspective. In M. Pitts \& M.J. Versluys (Eds.), Globalisation and the Roman world: World history, connectivity and material culture (pp. 99-122).

Cambridge University Press.

Livy. History of Rome, trans. Rev. Canon Roberts. (1912). New York: E. P. Dutton \& Co.

Mas, C., Cau, M. Á., Gurt, J. M., \& Sales, M. (2007). El poblamiento rural de Menorca durante la Antigüedad tardía: primera aproximación. Revista de Menorca, 90(1), 177-215.

Mascaró Pasarius, J. (1958). Els monuments megalítics a l'illa de Menorca (Vol. 19). Institut d'Estudis Catalans.

Micó, R. (2006). Radiocarbon dating and Balearic prehistory: reviewing the periodization of the prehistoric sequence. Radiocarbon, 48(3), 421-434.

Morely, N. (2015). Globalisation and the Roman economy. In M. Pitts \& M.J. Versluys (Eds.), Globalisation and the Roman world: World history, connectivity and material culture (pp. 46-68). Cambridge University Press.

Moreno Pérez, A.S. (2012). La religión romana en Menorca: aproximación desde las fuentes iconográficas. $\quad$ Lucentum, $31, \quad 177-194$. http://dx.doi.org/10.14198/LVCENTVM2012.31.10

Moreno Torres, S. (2005). Rutas de navegación en el Mediterráneo Occidental: condicionantes atmosféricos y aspectos técnicos de la navegación en la antigüedad. Mayurqa, 781-800.

Murray, M.A. (1932). Cambridge excavations in Minorca (Vol. 1). B. Quaritch.

Nicolás, J.C. de (1983). Romanización de Menorca. Geografía e Historía de Menorca, 4, 201-283.

Nicolás Mascaró, J.C. de (2003). Els primers segles de l'ocupació romana de l'illa de Menorca: continuïtats i ruptures en l'àmbit rural. Mayurqa, 29, 111-128.

Orfila, M. (2008). La intervención de Q. Cecilio Metelo sobre las Baleares (123 a 121 a. C.). Condiciones previas y sus consecuencias. Pyrenae, 39(2), 7-45.

Orfila, M. (1995). Arqueología romana. In M. Orfila Pons, C. Rita Larrucea, L. Plantalamor Massanet, \& F. Tuset Bertran (Eds.), Enciclopedia de Menorca (Vol. 8, pp.195-264). Obra Cultural de Menorca.

Orfila, M. (1993). Construcciones rurales romanas en Mallorca. In J. Padró i Parcerisa (Ed.), Homenatge a Miquel Tarradell. Estudis Universitaris Catalans (pp. 793-805). Curial.

Orfila, M., Sánchez, E., Gutiérrez, M., \& Marín, P. (2017). Religio Balearica: La Continuidad Cultual de los Santuarios Talayóticos en Época Romana. In T. Tortosa \& S.F. Ramallo Asensio (Eds.), El Tiempo Final de los Santuarios Ibéricos en los Procesos de Impacto y Consolidación del Mundo Romano (pp. 213-230). Consejo Superior de Investigaciones Científicas. 
Orfila Pons, M. (2007). Circunstancias y consecuencias de la intervención militar de Quito Cecilio Metelo sobre las Baleares (123 aC 121 aC). Revista de Menorca, 90(1), 69-113.

Orfila Pons, M. (1983). Estatuillas de bronce antiguas. In J. Mascaró Pasarius (Ed.). Geografía e Historia de Menorca (Vol. 4, pp. 85-158). J. Mascaró Pasarius.

Orfila Pons, M., \& Sintes Espasa, G. (1984). Estudio Preliminar Sobre la Perduracion del Habitat enlos Conjuntos Talayoticos Menorquines. Mayurqa, 20, 19-46.

Orfila Pons, M., \& Taltavull Femenías, E. (1996). An archaeological guide of Menorca. s.n.

Orosius. Historiarum Adversum Paganos Libri VII, ex recogn. Zangemeister, C. (1889). Teubner.

Osborne, J.F. (2017). Counter-monumentality and the vulnerability of memory. Journal of Social Archaeology, 17(2), 163-187.

Osborne, J.F. (Ed.). (2014). Approaching monumentality in archaeology. SUNY Press.

Parker Pearson, M. (2004). Island prehistories: A view of Orkney from South Uist. In J.F. Cherry, C. Scarre, \& S. Shennan (Eds.). Explaining social change: Studies in honour of Colin Renfrew (pp. 127-140). McDonald Institute.

Pérez-Jordà, G., Peña-Chocarro, L., Picornell-Gelabert, L., \& Carrión Marco, Y. (2018). Agriculture between the third and first millennium BC in the Balearic Islands: The archaeobotanical data. Vegetation History and Archaeobotany, 27, 253-265. https://doi.org/10.1007/s00334-017-0618-y

Pérez-Juez, A. (2011). Excavaciones en la Casa 2 del yacimiento de Torre d'en Galmés, Alaior: propuestas para el hábitat talayótico. III Jornadas d'Arqueologia de les Illes Balears. Consell Insular de Menorca, Mao, Menorca, 119-129.

Pliny the Elder. The Natural History, trans. Bostock, J., \& Riley, H.T. (1855). Taylor \& Francis. Prados, F., Jiménez, H., \& Martínez, J.J. (Eds.) (2017). Menorca entre Fenicios y Púnicos, 2. CEPOAT.

Puig Palerm, A. (2005). L'entrada de Mallorca en l'esfera imperialista de la República romana. Una contextualització històrica de l'evidència arqueològica anterior a la conquista romana del 123 aC. In M. Barceló Crespí, \& M.L. Sánchez de León (Eds.). XXIII Jornades d'Estudis Històrics Locals: L'Antiguitat clàssica i la seva pervivència a les Illes Balears (pp. 247-259). Palma de Mallorca: Institut d'Estudis Baleàrics.

Rainbird, P. (2007). The archaeology of islands. Cambridge University Press.

Ramis, D. (2010). From colonisation to habitation: Early cultural adaptations in the Balearic Bronze Age. In P. Van Dommelen \& A. Knapp (Eds.), Material connections in the Ancient Mediterranean: Mobility, materiality and identity (pp. 64-84). Routledge.

Ramón Torres, J. (2017). Pecios y ¿colonias? Materiales púnicos en las Islas Baleares. In F. Prados, H. Jiménez, \& J.J. Martínez (Eds.). Menorca entre Fenicios y Púnicos (pp. 41-84). CEPOAT.

Renfrew, C. (2013). The sanctuary at Keros: Questions of materiality and monumentality. Journal of the British Academy, 1, 187-212.

Renfrew, C. (1983). The social archaeology of megalithic monuments. Scientific American, 249(5), 152-163.

Renfrew, C. (1976). Megaliths, territories and populations. In S.J. De Laet (Ed.), Acculturation and continuity in Atlantic Europe Mainly During the Neolithic Period and the Bronze Age: Papers Presented at the IV Atlantic Colloquium (Vol. 16, pp. 198-220). De Tempel. 
Robb, J. (2001). Island identities: Ritual, travel and the creation of difference in Neolithic Malta. European Journal of Archaeology, 4(2), 175-202. https://doi.org/10.1179/eja.2001.4.2.175

Roselló-Bordoy, G., Sánchez-Cuenca, R., \& Montaner Alonso, P. de (1974). Imhotep, hijo de Ptah. Mayurqa, 12, 123-142.

Ruiz de Arbulo Bayona, J. (1998). Rutas marítimas y tradiciones náuticas: cuestiones en torno a las navegaciones tirias al Mediterráneo occidental. Treballs del Museu Arqueologic d'Eivissa e Formentera/Trabajos del Museo Arqueologico de Ibiza y Formentera, 41, 25-48.

Sánchez León, M.L. (2003). La Ciudad de Mago (Maó, Menorca): Continuidades y Rupturas. Mayurqa, 29, 97-110.

Sánchez León, M.L. (2000). Movilidad geográfica y élites municipales en la Menorca romana (Siglo II dC.). Bolletí de la Societat Arqueologica Lul-liana: Revista d'estudis històrics, 56, 35-44.

Sintes Olives, E. \& Isbert Vaquer, F. (2009). Investigación arqueológica y puesta en valor del Recinto Cartailhac: una unidad doméstica del siglo II ANE en el poblado talayótico de Torre de'n Galmès. Patrimonio cultural de España, 1, 251-260.

Smith, A. (2020). Balearic indigeneity in a global Mediterranean: Considering circular domestic structures of Late Iron Age Menorca. Mediterranean Archaeologies of Insularity in an Age of Globalization, 151.

Smith, A.J. (2015). Indigeneity and colonial response: The metamorphoses of Balearic culture in the Late Iron Age. Doctoral dissertation. Brown University.

Smith, A., \& van Dommelen, P. (2018). Monumental engagements: Cultural interaction and island traditions in the West Mediterranean. In A. Knodell \& T. Leppard (Eds), Regional Approaches to Society and Complexity. Studies in Honor of John F. Cherry (pp. 158-181). Equinox.

Starr, C.G. Jr. (1943). Coastal Defense in the Roman World. The American Journal of Philology, 64(1), 56-70.

Strabo. Geography, Volume I: Books 1-7, trans. Hamilton, H.C. \& Falconer, W. (1903). George Bell \& Sons.

Tilley, C.Y. (1994). A phenomenology of landscape: Places, paths, and monuments. Berg.

Trigger, B.G. (1990). Monumental architecture: A thermodynamic explanation of symbolic behaviour. World Archaeology, 22(2), 119-132.

Valenzuela, A., Alcover, J.A., \& Cau, M.Á. (2017). The impact of Roman conquest on the pattern of livestock exploitation on the Balearic Islands. Archaeofauna, 26, 127-142.

Van Strydonck, M. (2014). From Myotragus to Metellus. A journey through the pre-and early-history of Majorca and Minorca. Librum Publishers \& Editors.

Vella, C. (2016). Constructions of consensus: Monument building and the Fourth to First Millennium BC in the Central Mediterranean Islands. Journal of Mediterranean Archaeology, 29(2).

Zucca, R. (1998). Insulae Baliares. Le Isole Baleari sotto il Dominio Romano. Carocci. 